\title{
Evaluation of homeopathic treatments in early lactation in buffalo cows and neonatal mortality in buffalo calf
}

\author{
Fiorella Sarubbi", Rodolfo Baculo, Raffaele Palomba, Giuseppe Auriemma \\ National Research Council, ISPAAM Institute, Naples, Italy; *Corresponding Author: fiorella.sarubbi@cnr.it
}

Received 20 April 2012; revised 27 May 2012; accepted 15 June 2012

\begin{abstract}
The trial was conducted on thirty buffalo cows subdivided in three groups. In the immediate pre-calving, $2.5 \mathrm{ml}$ of Echinacea purpurea were orally administered to the first group (A) and, after calving, Nux vomica, Chelidonium and $L y-$ copodium were administered at 7 days intervals. The second group (B) was only subjected to the post-calving treatment, while the third group (C) represented the control group. Immediately after calving two groups of calves were formed. The first group received 5 granules of Pyrogenium in the first days of life and then for $\mathbf{1 0}$ days the $\mathbf{0 . 5}$ $\mathrm{ml}$ of $E$. purpurea. The second group did not receive any remedy. Before the calving, in conventional farm twenty buffalo cows (D group) were vaccinated. Remedies administration did not affect milk protein content, milk lipid contents and the achievement of the lactation peak. Blood samples showed that total protein, albumin and globulin levels were lower in group A, compared to groups B and C. Cholesterol and urea were lower in the treated groups than in the control. We therefore conclude that the use of homeopathic remedies are a chance to improve animal welfare and their productive characteristics.
\end{abstract}

Keywords: Buffalo Cows; Buffalo Calf; Homeopathic Remedy; Neonatal Mortality; Milk Production; Metabolic Profiles

\section{INTRODUCTION}

In Italy, the breeding of Mediterranean buffalo (Bubalus bubalis) is an important economic and social reality, for the large number of personnel involved, for the economic and productive profits, becoming a strategic point for the economy a whole area. The attention is devoted, especially in the production process, to the reduction of drugs employed in the farm, like pesticides, antibiotics and vaccines; in fact some farmers, rightly encouraged by the opportunity to obtain products of different nutritional and organoleptic characteristics, responding better to the new demands of the consumer, sold at a higher price, have transformed their conventional farm in an organic breeding.

The last stage of pregnancy and the first few months of life of the calf represent a crucial phase in the management of buffalo farm's because these phases are critical for transmission of immunity defences by maternal way [1] because the calf is unable to respond to major environmental agents, pathogens and non, that cause the high neonatal mortality (from 10\% - 15\%) and the high mortality in the first three months of calf life (30\% to $45 \%$, unpublished data). This situation drives a development of infectious diseases of high mortality, showing symptoms affecting the gastrointestinal apparatus with diarrhoeic events leading to severe dehydration that often carries the calf to death [2]. To deal this situation the farmers use commercial products that help stimulating the immune system against the main pathology caused by Clostridia, E. coli, Rotavirus and Coronavirus. Is important to know that the buffalo calves, like all other ruminants, missing of circulating immunoglobulin (Ig), for placenta impermeability to the Ig, and only the recruitment of the colostrums Ig gives them an adequate immunity in the neonatal period [3], until the development of their self immune system. The maternal antibodies, giving a passive immunization if the intake of colostrums occurs one hour after birth, are transferred, after ingestion, from the intestinal lumen to the blood of the calf within 24 hours after calving [4]. The intestine ability of Ig absorption set up quickly, to become negligible when the cells appointed to this absorption are replaced by more mature cells that do not absorb macromolecules [5]: this happens 8 hours after birth in cattle calves, and 1 to 5 hours in buffalo calves if they take colostrums after 30 min from birth. Parveen (1998) [6] showed that the closing of the intestine in buffalo calf occurs within 5 hours 
after birth if the intake of colostrums occurred at 1 hour of age, or within 4 hours from the administration of the colostrums. This rapid closing of intestine reduces the incidence of infections in the calves [7]. Hence the need for early and proper administration of colostrums to the calves, as its failure or delayed recruitment or its poor quality predisposes the animals to neonatal infections $[8,9]$. Moreover, poor hygiene, the incorrect diet as well as lack or inadequate intake of colostrums, are the most important factors that promote the onset of diseases, as reported by Galiero (2001) [10]. Hence it is an obvious opportunity to reserve a particular attention to environmental conditions (hygiene, nutrition, management, etc.) in the pre-calving phases in buffalo cows and in the first three months of life of buffalo calf. This phase will determine significantly the economy and development of the farm.

This situation leads to symptoms affecting the gastrointestinal tract, characterized by diarrhoea leading to dehydration, anorexia and then death of the calf. The clinical picture is due to an attack by viruses and bacteria in the small intestine, causing intestinal desquamation of epithelium. The Conventional farm usually employs the vaccination techniques while the Organic farm relies on a homeopathic approach.

The administration of homeopathic remedies, acting detoxicating, immune-stimulating and stimulating the production processes in cows in the first stage of lactation, has significantly improved the production of milk [11]. The period of pregnancy is considered the best time for the action of homeopathic remedies. In this period, the buffalo cows would show greater sensitivity to the doses of homeopathic remedies involving the physical economy as a whole [12]. Beuscher et al. (1995) [13] showed that roots extracts of three medicinal species of Echinacea (E. purpurea, E. angustifolia, E. pallida) contain immunologically active substances and are able to oppose to the depressive action on the immune system typical of many antibiotics [14,15].

Echinacea purpurea is a species of flowering plant in the genus Echinacea who's its cone-shaped flowering heads are usually purple, native to eastern North America and present in the wild in several tows of the United States. It is also grown as an ornamental plant, and numerous cultivars have been developed for flower quality. One study shows E. purpurea has antidepressant properties in white rats as it increased the stimulating action of L-DOPA [16].

It was considered appropriate to study the effects of homeopathic remedies (Nux vomica, Chelidonium and Lycopodium) in the organic farm for their "stimulant factors" on the therapeutic action, for the lack of direct or indirect toxicity, for the low cost and the fast immu- nological response. The knowledge of the effects and mechanisms of homeopathic remedies are incomplete and controversial [17] and also the ways of actions of $E$. purpurea are poorly characterized and in no way comprehensive.

Nux vomica is a deciduous tree native to India and Southeast Asia. It is a medium-sized tree in the family Loganiaceae that grows in open habitats. It is a major source of the highly poisonous alkaloids strychnine and brucine, derived from the seeds inside the tree's round, green to orange fruit. The seeds contain approximately $1.5 \%$ strychnine, and the dried blossoms contain $1.0 \%$ [18].

Chelidonium is an herbaceous perennial plant; it is native to Europe and western Asia and widely introduced in North America.

The whole plant is toxic in moderate doses as it contains a range of isoquinoline alkaloids but there are numerous therapeutic uses when used at the correct dosage. The main alkaloid present in the herb and root is coptisine. Other alkaloids present include methyl 2'-(7,8dihydrosanguinarine-8-yl)acetate, allocryptopine, stylopine, protopine, norchelidonine, berberine, chelidonine, sanguinarine, chelerythrine and 8-hydroxydihydrosanguinarine. Sanguinarine is particularly toxic with and LD50 of $18 \mathrm{mg}$ per $\mathrm{kg}$ body weight. Caffeic acid derivatives are also present. Some alkaloids have shown potential activity against methicillin-resistant Staphylococcus aureus. The effect of the fresh herb is of a mild analgesic, cholagogic, antimicrobial, oncostatic and central nervous system sedative. In vitro experiments on animal cells celandine is shown to be cytostatic [19] an immune stimulating effect has also been noted. Some studies show that the alkaloid extraction can have the same effects. The alkaloids are known to cause immobilization in mice after being taken orally or injected. The alkaloids cause limpness and tone reduction of smooth muscle in rabbits. The alkaloids are also noted to stimulate the heart and lungs of frogs, cats and dogs, raising the blood pressure and widening the arteries [20-22].

Lycopodium is the most widespread species in the genus Lycopodium of the clubmoss family Lycopodiaceae. Lycopodium is adapted more especially to ailments gradually developing, functional power weakening, with failures of the digestive powers, where the function of the liver is seriously disturbed.

Aim of this work was to improve the knowledge of the effects of administration of Echinacea on neonatal mortality in organic and conventional buffalo livestock; it is also intended to study the effects of administration of homeopathic detoxicating, immune-stimulating and production-stimulating remedies (Nux vomica, Chelidonium and Lycopodium) in the pre- and post-partum in buffalo cows. 


\section{MATERIAL AND METHODS}

\subsection{The Herds}

This study was conducted at an organic and conventional farms located in the south Italy, both near Salerno.

In the organic farms the breeding facilities are spacious, modern and comfortable. The pastures belong to the same farm. The vanguard milking techniques guarantee impeccable hygiene, superior milk quality and well-being of the animals in fact the introduction of robots for the milking have changed the milking process itself: the buffaloes regained a more natural and less distressing rhythm of life, they can decide themselves when to give milk. The farmers on the other hand no longer need to subject themselves to the animals needs but assume the role of observers and supervisors.

In Conventional farming the herd has about 1800 animals of which 800 adults and 600 from comeback. They milked 500 head twice a day, with an average of 23 tons per year of lactation per head. Artificial insemination is practiced by the '80s, in addition to improving livestock genetics has helped to focus it shares seasonal variations in spring-summer, and autumn births would naturally clashing with the demands of the market.

\subsection{Farms Investigations}

In the organic farm, 30 pluriparous buffaloes, uniform for stage of calving and parity (all in third lactation), were selected for the test on early lactation, while 20 pluriparous buffaloes, uniform for stage of calving and parity (all in third lactation), were considered in the conventional farm. In the organic farm, the animals were divided in three groups, labelled A (treated group in the pre-and post-calving), B (treated only in post-calving) and $\mathrm{C}$ (control) group. The pre-calving treatment provided the administration of $2.5 \mathrm{ml} / \mathrm{animal} /$ day of Echinacea purpurea (TM) per os for 20 days, while in the post-partum Nux vomica $30 \mathrm{CH}$ (10 pellets/head/day) for the first 7 days, Chelidonium $30 \mathrm{CH}$ (10 pellets/head/day) for further 7 days and Lycopodium (10 pellets/head/day) for the last 7 days were used. All administrations were done orally and immediately after the morning milking, before feeding.

In the conventional farm the buffalo cows were vaccinated using commercial products, containing inactive strains of bacteria (Coli and Clostridria), and viruses (Rotavirus and Coronavirus).

In the organic farm, buffaloes were eating, in the precalving phases, a diet composed by $59 \%$ of silo spring, $35 \%$ wheat straw and $6 \%$ organic feed; after calving the diet was composed by $25.2 \%$ of maize silage, $6.9 \%$ of clover hay, $6.9 \%$ of medical hay, $51.8 \%$ of fresh lolium italicum and $9.7 \%$ of organic feed, while, in conventional farm, the buffalo cows were fed with wheat straw (57\%), white bean meal (24\%) and maize silage (19\%).

The chemical characteristics, expressed in \% on DM, were determined according to the methodology suggested by AOAC (1998) [23], and are reported in Table 1.

In each farm the daily quantity of milk produced was measured, and every week the quality of milk (fat content, protein content and somatic cells count) was determined. At the beginning of the trial $\left(\mathrm{T}_{0}\right)$ and every two weeks the analysis was performed on blood samples taken from the jugular vein by the Vacutainer method, and the following parameters were determined: glucose, cholesterol, total protein, urea, albumin, globulin, creatinine, GOT and GPT.

In the organic farm, the buffalo calves were divided, after birth, in two groups. The first group was treated with 5 granules of Pyrogenium diluted in $5 \mathrm{ml}$ of acid milk in the first days of life and then for 10 days with 0.5 $\mathrm{ml} /$ day of Echinacea purpurea (TM) in $5 \mathrm{ml}$ of acid milk.

The data were processed by ANOVA using the statistical package SPSS (2003) [24].

Table 1. Chemical characteristics of unifeed expressed in \% on DM.

\begin{tabular}{lllll}
\hline & \multicolumn{3}{c}{ Organic farm } & \multicolumn{2}{c}{ Conventional farm } \\
\cline { 2 - 5 } & Unifeed (buffalo dry) & Unifeed (buffalo cows) & Unifeed (buffalo dry) & Unifeed (buffalo cows) \\
\hline Crude protein & $6.87 \pm 0.86$ & $12.31 \pm 1.77$ & $5.33 \pm 0.54$ & $15.30 \pm 2.01$ \\
Crude fibre & $20.01 \pm 2.12$ & $18.82 \pm 1.89$ & $16.58 \pm 1.98$ & $17.30 \pm 1.56$ \\
Fat & $2.20 \pm 0.77$ & $2.14 \pm 0.54$ & $3.02 \pm 0.64$ & $6.02 \pm 0.75$ \\
Starch & $2.61 \pm 0.53$ & $24.81 \pm 6.98$ & $2.57 \pm 0.42$ & $24.00 \pm 5.98$ \\
NSC & $61.0 \pm 10.75$ & $42.85 \pm 8.69$ & $58.23 \pm 7.89$ & $34.78 \pm 7.12$ \\
Milk Forage Units/Kg of dry matter & 0.60 & 0.90 & 0.68 & 0.96 \\
\hline
\end{tabular}




\section{RESULTS AND DISCUSSION}

In our experimental conditions, the administration of homeopathic remedies acting stimulating the digestive processes and detoxicating (Nux vomica and Chelidonium) and immune-stimulant (Echinacea purpurea and Lycopodium) in the pre- and post-calving, improved the milk yield $(\mathrm{P}<0.001)$ in the organic farm. The protein content of milk was not influenced by the treatment, while the fat content was greater in the group treated only in the post-calving. The content of the milk somatic cells, as a sign of the health of the mammary gland, has an optimal value in all groups, and was found signifycantly lower in the treated animals. The results are reported in Table 2.

The characteristics of milk in the conventional farm were the following (Table 3).

Table 4 shows the differences between biological and conventional managements.

These differences are to be referred to the managerial conduction of the farms.

Figure 1 shows the trend of the lactation curve in the first 120 days of lactation in treated in pre- and postpartum (A), treated only in post-partum (B) and untreated groups $(\mathrm{C})$ in organic farm and vaccinated group in conventional farm.

The peak of lactation was reached in 50 days for group A, 57 days for group B and C, and 62 days for vaccinate group.

Chemical haematic profile in organic farm is reported in Table 5, while that of the conventional farm is reported in Table 6.

Table 2. Effect of administration of homeopathic remedies on the parameters of milk in organic farm.

\begin{tabular}{lcccc}
\hline & & Control group & A group & B group \\
\cline { 3 - 5 } & & means \pm SD & means \pm SD & means \pm SD \\
\hline Milk yield & $\%$ & $8.95 \pm 2.13$ & $10.04 \pm 2.54$ & $8.20 \pm 2.82$ \\
fat & $\%$ & $8.02 \pm 0.92$ & $8.16 \pm 1.31$ & $8.57 \pm 1.60$ \\
protein & $4.71 \pm 0.73$ & $4.01 \pm 0.65$ & $3.97 \pm 0.63$ \\
somatic cell count & unit/mL & $222.75 \pm 96.24$ & $150.60 \pm 45.29$ & $170.00 \pm 45.29$ \\
\hline
\end{tabular}

Table 3. Effect of administration of homeopathic remedies on the parameters of milk in conventional farm.

\begin{tabular}{lcc}
\hline & Units & Conventional group \\
\cline { 3 - 3 } & & means \pm SD \\
\hline Milk yield & Kg & $9.51 \pm 2.34$ \\
Fat content & $\%$ & $8.07 \pm 0.28$ \\
Protein content & $\%$ & $4.80 \pm 0.11$ \\
somatic cell count & unit/mL & $317.72 \pm 87.72$ \\
\hline
\end{tabular}

Table 4. ANOVA.

\begin{tabular}{lcccc}
\hline & \multicolumn{3}{c}{ Organic farm } & Conventional farm \\
\cline { 2 - 4 } & Control Group & Group A & Group B \\
\hline Milk yield & $*$ & $*$ & $*$ & $*$ \\
Fat content & n.s. & n.s. & $* *$ \\
Protein content & n.s. & $* *$ & $* *$ & $* *$ \\
somatic cell count & $* *$ & $* *$ & $* *$ & $* *$ \\
\hline
\end{tabular}




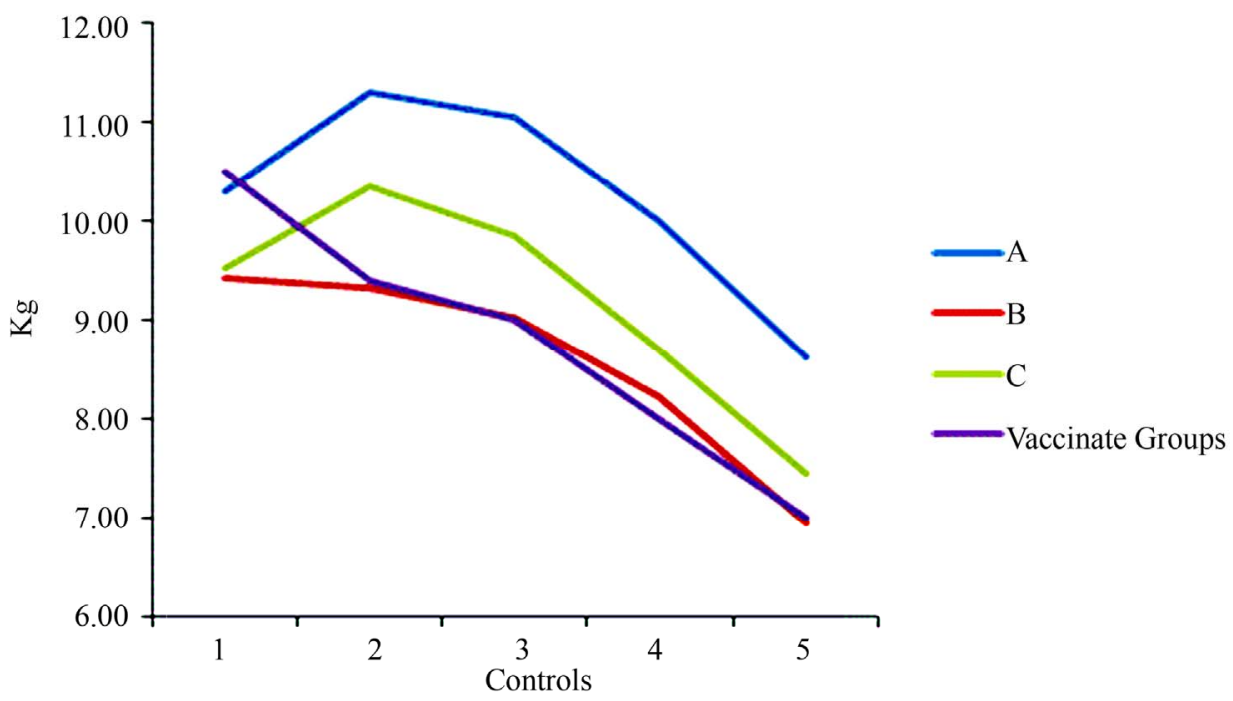

Figure 1. The average change in production $(\mathrm{Kg})$ during the first 120 days of lactation in the three treated and in vaccinated groups.

Table 5. Chemical haematic profile on treated buffaloes at $\mathrm{T}_{0}, \mathrm{~T}_{14}$ and $\mathrm{T}_{21}$ in organic farm.

\begin{tabular}{lcccc}
\hline & & $\mathrm{T}_{0}$ & $\mathrm{~T}_{14}$ & $\mathrm{~T}_{21}$ \\
\cline { 3 - 4 } & & means $\pm \mathrm{SD}$ & means $\pm \mathrm{SD}$ & means $\pm \mathrm{SD}$ \\
\hline Glucose & $\mathrm{mmol} / \mathrm{l}$ & $4.53 \pm 0.3 \mathrm{~b}$ & $5.54 \pm 0.6 \mathrm{a}$ & $4.18 \pm 0.9 \mathrm{~b}$ \\
Cholesterol & $\mathrm{mmol} / \mathrm{l}$ & $1.79 \pm 0.2 \mathrm{~b}$ & $2.5 \pm 0.2 \mathrm{a}$ & $2.11 \pm 0.6$ \\
Urea & $\mathrm{mmol} / \mathrm{l}$ & $8.05 \pm 0.9$ & $8.33 \pm 0.9 \mathrm{a}$ & $8.61 \pm 1.25 \mathrm{~b}$ \\
Total protein & $\mathrm{g} / \mathrm{l}$ & $44.7 \pm 4.2 \mathrm{~b}$ & $60.21 \pm 4.5 \mathrm{a}$ & $58.9 \pm 8.71 \mathrm{~b}$ \\
Albumin & $\mathrm{g} / \mathrm{l}$ & $25.03 \pm 3.4 \mathrm{~b}$ & $30.95 \pm 1.88 \mathrm{a}$ & $29.4 \pm 2.3 \mathrm{~b}$ \\
Globulin & $\mathrm{g} / \mathrm{l}$ & $22 \pm 5.2 \mathrm{~b}$ & $29.15 \pm 2 \mathrm{a}$ & $30.3 \pm 4.8$ \\
AST & $\mathrm{U} / \mathrm{l}$ & $108.2 \pm 9.5 \mathrm{~b}$ & $144.53 \pm 23.6 \mathrm{a}$ & $135.8 \pm 29.7 \mathrm{~b}$ \\
ALT & $\mathrm{U} / \mathrm{l}$ & $13.18 \pm 2.4 \mathrm{~b}$ & $21.6 \pm 2.9 \mathrm{a}$ & $13.11 \pm 1.28 \mathrm{~b}$ \\
NEFA & $\mathrm{mmol} / \mathrm{l}$ & $0.17 \pm 0.08 \mathrm{~b}$ & $0.20 \pm 0.02 \mathrm{a}$ & $0.31 \pm 0.08 \mathrm{~b}$ \\
$\beta$ OH-butyrate & $\mathrm{mmol} / \mathrm{l}$ & $0.26 \pm 0.07$ & $0.33 \pm 0.05$ & $0.30 \pm 0.08$ \\
Triglyceride & $\mathrm{mmol} / \mathrm{l}$ & $0.22 \pm 0.05$ & $0.25 \pm 0.03$ & $0.13 \pm 0.05$ \\
\hline
\end{tabular}

Chemical haematic profile on untreated buffalo cows at $\mathrm{T}_{0}, \mathrm{~T}_{14}$ and $\mathrm{T}_{21}$ in organic farm.

\begin{tabular}{lcccc}
\hline & & $\mathrm{T}_{0}$ & $\mathrm{~T}_{14}$ & $\mathrm{~T}_{21}$ \\
\cline { 3 - 4 } & & means $\pm \mathrm{SD}$ & means $\pm \mathrm{SD}$ & means $\pm \mathrm{SD}$ \\
\hline Glucose & $\mathrm{mmol} / \mathrm{l}$ & $5.09 \pm 0.72 \mathrm{a}$ & $4.77 \pm 0.70 \mathrm{~b}$ & $4.94 \pm 0.78 \mathrm{a}$ \\
Cholesterol & $\mathrm{mmol} / \mathrm{l}$ & $2.20 \pm 0.45 \mathrm{a}$ & $2.06 \pm 0.32 \mathrm{~b}$ & $2.10 \pm 0.40$ \\
Urea & $\mathrm{mmol} / \mathrm{l}$ & $8.01 \pm 0.98$ & $8.15 \pm 0.97 \mathrm{~b}$ & $9.37 \pm 0.98 \mathrm{a}$ \\
Total protein & $\mathrm{g} / \mathrm{g}$ & $53.65 \pm 9.4 \mathrm{a}$ & $49.53 \pm 4.76 \mathrm{~b}$ & $62.26 \pm 8.84 \mathrm{a}$ \\
Albumin & $\mathrm{g} / \mathrm{g}$ & $28.00 \pm 4.04 \mathrm{a}$ & $26.25 \pm 2.22 \mathrm{~b}$ & $31.15 \pm 4.80 \mathrm{a}$ \\
Globulin & $\mathrm{g} / \mathrm{l}$ & $25.54 \pm 5.54 \mathrm{a}$ & $23.27 \pm 3.37 \mathrm{~b}$ & $31.11 \pm 5.77$ \\
AST & $\mathrm{U} / \mathrm{l}$ & $132.05 \pm 26.97 \mathrm{a}$ & $116.49 \pm 18.15 \mathrm{~b}$ & $155.05 \pm 48.73 \mathrm{a}$ \\
ALT & $\mathrm{U} / \mathrm{l}$ & $17.70 \pm 3.30 \mathrm{a}$ & $14.92 \pm 3.73 \mathrm{~b}$ & $16.73 \pm 3.83 \mathrm{a}$ \\
NEFA & $\mathrm{mmol} / \mathrm{l}$ & $0.22 \pm 0.05 \mathrm{a}$ & $0.16 \pm 0.03 \mathrm{~b}$ & $0.37 \pm 0.09 \mathrm{~b}$ \\
$\beta$ OH-butyrate & $\mathrm{mmol} / \mathrm{l}$ & $0.30 \pm 0.09 \mathrm{a}$ & $0.26 \pm 0.02 \mathrm{~b}$ & $0.39 \pm 0.05 \mathrm{a}$ \\
Triglyceride & $\mathrm{mmol} / \mathrm{l}$ & $0.28 \pm 0.03 \mathrm{a}$ & $0.22 \pm 0.02 \mathrm{~b}$ & $0.15 \pm 0.03$ \\
\hline
\end{tabular}

AST: Serum Glutamic Oxaloacetic Transaminase; ALT: Serum Glutamic Pyruvic Transaminase; NEFA: non-esterified fatty acids; a, b is significant at the 0.01 . 
Table 6. Chemical haematic profile on vaccinated buffalo cows at $T_{0}, T_{14}$ and $T_{21}$ in conventional farm.

\begin{tabular}{lcccc}
\hline & & $\mathrm{T}_{0}$ & $\mathrm{~T}_{14}$ & $\mathrm{~T}_{21}$ \\
\cline { 2 - 5 } & & means $\pm \mathrm{SD}$ & means $\pm \mathrm{SD}$ & means $\pm \mathrm{SD}$ \\
\hline Glucose & $\mathrm{mmol} / \mathrm{l}$ & $5.82 \pm 0.40$ & $5.57 \pm 0.56$ & $5.79 \pm 0.61$ \\
Cholesterol & $\mathrm{mmol} / \mathrm{l}$ & $2.88 \pm 0.22$ & $2.36 \pm 0.36$ & $2.34 \pm 0.44$ \\
Urea & $\mathrm{mmol} / \mathrm{l}$ & $8.60 \pm 0.64$ & $8.80 \pm 0.54$ & $9.80 \pm 0.76$ \\
Total protein & $\mathrm{g} / \mathrm{l}$ & $63.30 \pm 1.54$ & $54.70 \pm 1.67$ & $68.40 \pm 2.01$ \\
Albumin & $\mathrm{g} / \mathrm{l}$ & $39.4 \pm 1.04$ & $44 \pm 0.98$ & $42.4 \pm 1.22$ \\
Globulin & $\mathrm{g} / \mathrm{l}$ & $31.8 \pm 4.14$ & $27.2 \pm 3.79$ & $28.5 \pm 3.98$ \\
AST & $\mathrm{U} / \mathrm{l}$ & $136 \pm 23.87$ & $132.2 \pm 25.01$ & $127.4 \pm 26.46$ \\
ALT & $\mathrm{U} / \mathrm{l}$ & $16.32 \pm 4.02$ & $16.37 \pm 3.79$ & $17.0 \pm 3.15$ \\
NEFA & $\mathrm{mmol} / \mathrm{l}$ & $0.20 \pm 0.04$ & $0.19 \pm 0.04$ & $0.22 \pm 0.03$ \\
$\beta$ BOH-butyrate & $\mathrm{mmol} / \mathrm{l}$ & $0.31 \pm 0.06$ & $0.28 \pm 0.05$ & $0.33 \pm 0.05$ \\
Triglycerides & $\mathrm{mmol} / \mathrm{l}$ & $0.30 \pm 0.04$ & $0.26 \pm 0.04$ & $0.22 \pm 0.05$ \\
\hline
\end{tabular}

AST: Serum Glutamic Oxaloacetic Transaminase; ALT: Serum Glutamic Pyruvic Transaminase; NEFA: non-esterified fatty acids; a, b is significant at the 0.01 .

The analysis of blood samples taken at 0, 14 and 21 days from calving, as shown in Table 5, showed lower values of total protein, albumin and globulin values for $\mathrm{A}$ and $\mathrm{B}$ groups compared to the $\mathrm{C}$ group in the first and third sampling. Similar trend is evident for glucose, cholesterol, urea, NEFA, $\beta \mathrm{OH}$-butyrate and triglycerides values. GOT values were found significantly lower in A and B groups in comparison to C group. Only in T14 the treated groups showed higher value for considered parameters.

In conventional farm the haematic profile shows higher values compared to those found in the organic farm. Figure 2 shows the number of calves born and dead in the different farms and the subdivision in males and females.

The organic farm showed 215 calving (135 males and 80 females), while the conventional farm showed 221 calving, divided in 91 males and 130 females; therefore the ratio male/female was significantly in favour of males in organic but was contrary in conventional farm. This situation is fortuitous.

The dead calves were 71 out of 215 births in organic farm. In this farm the mortality for the first week was $10 \%$ and increased through the second and third month in both groups of calves (treated and not treated), and the general mortality of the organic farm was $33.17 \%$. This situation is due to the characteristics of E. Purpurea, that helps the calves in the critical period of immunization from the birth to the administration of colostrums. When subdividing the mortality over the time it is evident that the treated group has a critical moment in the $2-3$ months interval, while for non-treated group this is in the first month. This distribution is due to the alimentary stress linked to the transition from a liquid to a solid feeding received by animals in the 2 - 3 months period. This alimentary stress changes the intestinal micro population and represents a situation not manageable by Echinacea. This problem can be afforded with a different management and with homeopathic remedies favouring the normal physiologic change in this period of calf life, for example carbonic calcarea.

The most critical moment in calf life is the beginning of the consumption of solid feedstuff, corresponding to the reduction in milk consumption. Milk consumption determines the modulation of the gastrointestinal microbial development, provided by lactose, caseins, lysozyme, and lactoferrin. For this reason, removing the milk determines an alteration of the internal flora. In this phase there is a reduction of the populations of lactobacilli and enterococci. At the same time, the protozoa microfauna (like Entodinea spp., Diplodinea spp., Holotrichs spp., etc) appears in the rumen. In subsequent steps, the definitive associations typical of the adult animal are realized.

On the contrary, in conventional farm, where the dead calves were 73 out of 221 births, the mortality was 14\% in the first week, $11 \%$ in the first month, $10 \%$ through the second and third month and 33\% in the first three months of calf life.

This dictates to give a particular attention to the environmental conditions, such as hygienic and alimentary, in the first three months of calf life.

In the experimental conditions the administration of homeopathic remedies like immune-stimulant and detoxificant to the buffalo in pre- and post-partum and to the calves in the first 10 days of life, has remarkably reduced the percentage of neonatal mortality in the organic farm. 


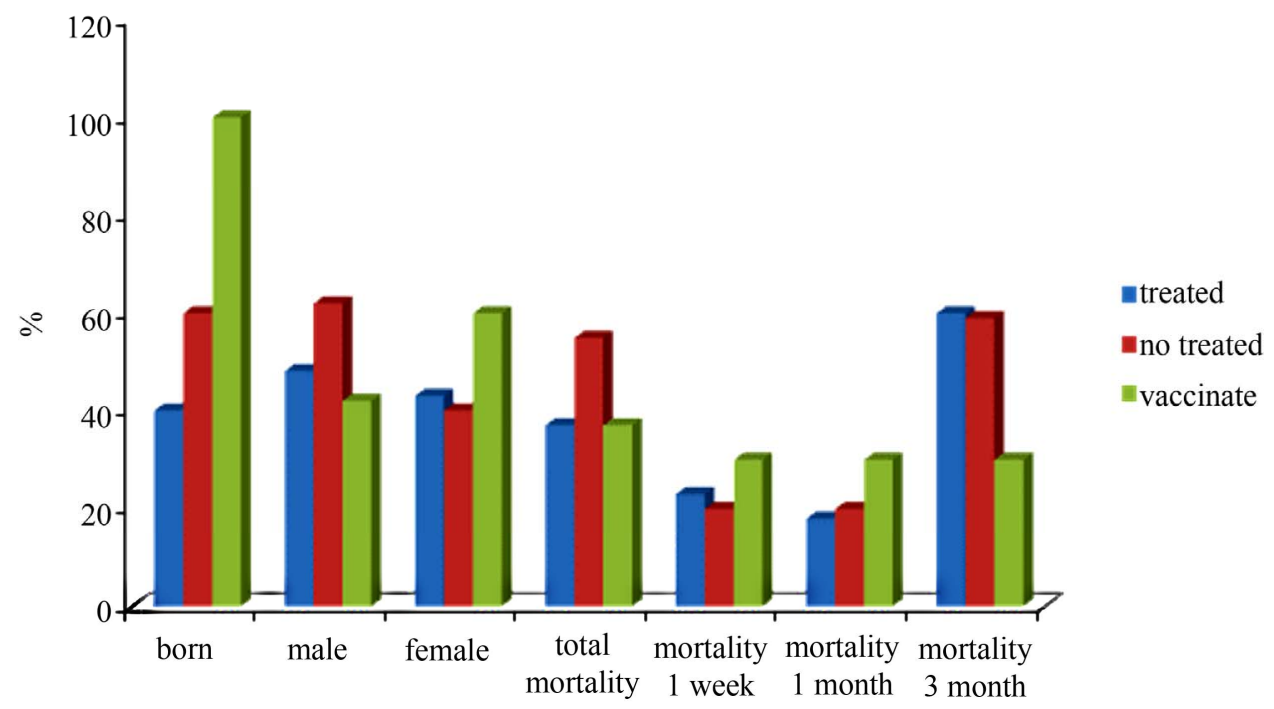

Figure 2. Distribution of births and deaths of calves in organic and conventional farms.

The homeopathic procedure shows the absence of collateral effects respecting the animal welfare, the possibility to treat the groups at the same time with consequent reduction of suspension time, absence of drug resistance and residual in the production (milk and meat).

We therefore conclude that the use of homeopathic remedies are not only a therapeutic weapon, but also a chance to improve animal welfare and their productive characteristics.

\section{ACKNOWLEDGEMENTS}

The authors are grateful to Giuseppe Grazioli for the technical assistance.

\section{REFERENCES}

[1] Levieux, D. (1984) Transmission de l'immunité passive colostrale: Le point des connaissances. In: Jarrige, R., Ed., Physiologie et pathologie périnatales chez les animaux de farme, INRA Paris, 345-369.

[2] Sarubbi, F. (2002) Principali cause di diarrea nei vitelli bufalini e possibili approcci omeopatici. Thesis of Specialization in Homeopathic Veterinary Medicine.

[3] Brambell, F.W.R. (1969) The transmission of passive immunity from mother to young, north Holland research monograph. Frontiers of Biology, 18.

[4] Zaremba, W., Guterbock, W.M. and Holmberg, C.A. (1993) Efficacy of dried colostrums powder in prevention of disease in neonatal Holstein calves. Journal Dairy Science, 76, 831-836. doi:10.3168/jds.S0022-0302(93)77408-1

[5] Tizzard, I. (1982) Immunity in foetus and newborn animals P.155. In: An Introduction to Veterinary Immunology, W.B. Saunders Company, Philadelphia, USA, Handbook, FAO, ISBN 0-7216-4686-7.

[6] Parveen, A.S.P. (1998) Maternal-neonatal transfer and intestinal absorption of immunoglobulin in buffaloes. Bubalus bubalis, 4, 56-67.

[7] Singh, A. and Ahuja, S.P. (1993) Individual variation in the composition of colostrums and absorption of colostral antibodies by the pre-colostral buffalo calf. Journal Dairy Science, 76, 1148-1156. doi:10.3168/jds.S0022-0302(93)77443-3

[8] Matte, J.J., Girrad, C.L., Seaone, J.R. and Braisson, G.J. (1982) Absorption of colostral immunoglobulin G in the newborn dairy calf. Journal Dairy Science, 65, 17651770.

[9] N'Diaye, Wereme, A., Strabel, M., Grongnet, J.-F. and Piot, M. (2001) Immunoglobulin G absorption from pooled maternal colostrum, commercial powder and freeze-dried colostrum by newborn calves. Animal Research, 50, 315-323. doi:10.1051/animres:2001133

[10] Galiero, G. (2001) Principali agenti eziologici delle patologie neonatali del vitello bufalino. Terapia e profilassi Atti I Congresso Nazionale sull’Allevamento del Bufalo, 3-5 ottobre, Eboli (Sa), 51-59.

[11] Sgoifo Rossi, C.A., Dell’Orto, V., Peri, V. and Pinotti, L. (1997) Impiego di rimedi omeopatici nella prima fase di lattazione di bovine ad alta produzione. Proceeding SiSvet, 461-462.

[12] Del Francia, F. (1980) Trattato d'omeopatia veterinaria. Siderea Roma.

[13] Beuscher, N., Bodinet, C., Willigmann, I. and Egert, D. (1995) Immune modulating properties of root extracts of different Echinacea species. Zeitschrift Phytotherapie, 16, 157-166.

[14] Burger, R.A., Torres, A.R., Warren, R.P., Caldwell, V.D. and Hughes, B.G. (1997) Echinacea-induced cytokine production by human macrophages. International Journal of Immunopharmacology, 19, 371-379. doi:10.1016/S0192-0561(97)00061-1

[15] Percival, S.S. (2000) Use of Echinacea in medicine. Biochemical Pharmacology, 60, 155-158. doi:10.1016/S0006-2952(99)00413-X 
[16] Kurkin, V.A., Dubishchev, A.V., Ezhkov, V.N., Titova, I.N. and Avdeeva, E.V. (2006) Antidepressant activity of some phytopharmaceuticals and phenylpropanoids. Pharmaceutical Chemistry Journal, 40, 614-619. doi:10.1007/s11094-006-0205-5

[17] De Verdier, K., Öhagen, P. and Alenius, S. (2003) No effect of a homeopathic preparation on neonatal calf diarrhoea in a randomised double-blind, placebo-controlled clinical trial. Acta Veteterinaria Scandinava, 44, 97-101. doi:10.1186/1751-0147-44-97

[18] Akbar, S., Khan, S.A., Akbar, M and Iqbal, M. (2010) Use of Strychnos nux-vomica (azraqi) seeds in Unani system of medicine: Role of detoxification. African Journal of Traditional, Complementary, and Alternative Medicines, 7, 286-290. doi:10.4314/ajtcam.v7i4.56689

[19] Nawrot, R., Wolun-Cholewa, M. and Gozdzicka-Jozefiak, A. (2008) Nucleases isolated from Chelidonium majus L. milky sap can induce apoptosis in human cervical carcinoma HeLa cells but not in Chinese Hamster Ovary CHO cells. Folia Histochemica et Cytobiologica, 46, 79-83. doi:10.2478/v10042-008-0011-x
[20] Cahlikova, L., Ople and l, L., Kurfurst, M., Macakova, K., Kulhankova, A. and Host'alkova, A. (2010) Acetylcholinesterase and butyrylcholinesterase inhibitory compounds from Chelidonium majus (Papaveraceae). Natural Product Communications, 5, 1751-1754.

[21] Li, X.-L., Yao, J.-Y., Zhou, Z.-M., Shen, J.-Y., Ru, H.-S. and Liu, X.-L. (2011) Activity of the chelerythrine, a quaternary benzo[c]phenanthridine alkaloid from Chelidonium majus L. on Dactylogyrus intermedius. Parasitology Research, 109, 247-252. doi:10.1007/s00436-011-2320-9

[22] Park, J.E., Cuong, T.D., Hung, T.M., Lee, I., Na, M., Kim, J.C., Ryoo, S., Lee, J.H., Choi, J.S., Woo, M.H. and Min, B.S. (2011) Alkaloids from Chelidonium majus and their inhibitory effects on LPS-induced NO production in RAW264.7 cells. Bioorganic and Medicinal Chemistry Letters, 21, 6960-6963. doi:10.1016/j.bmcl.2011.09.128

[23] AOAC (1998) Methods of analysis association official analysis chemical. Official Washington DC.

[24] SPSS 12.0 Package software (2003) 